\title{
ANALISIS FAKTOR-FAKTOR YANG MEMPENGARUHI MINAT MAHASISWA JURUSAN MANAJEMEN BISNIS STIE MIKROSKIL DALAM KEIKUTSERTAAN BISNIS MULTI LEVEL MARKETING
}

\author{
Hanny Siagian \\ STIE MIKROSKIL \\ email: hanny@mikroskil.ac.id
}

\begin{abstract}
The research objective is to identify and analyze the factors that affectingthe interest of business management student of STIE Mikroskil in participating Multi Level Marketing (MLM) business. The method used in this study is a survey approach, this kind of research is a quantitative and descriptive explanatory. The methods of data collection is done by providing a list of written questions and documentation study. Data analysis method used is multiple linear regression using SPSS software. The results of the research that has been carried out simultaneously showed that a small capital, flexible time, require experience and be able to determine the income have significant impact on the STIE Mikroskil student's decision. Partially small capital has positive and significant impact on student's decision. Time flexible partially has positive and significant impact on student's decision. Partially do not require experience has positive and significant impact on student's decision. Partially, be able to determine the income has positive and significant impact on student's decision. This research showed that the income can determine a positive impact on improving student's decision.

Keywords: small capital, flexible time, require experience, be able to determine the income and student's decision
\end{abstract}

\begin{abstract}
Abstrak
Tujuan penelitian ini untuk mengetahui dan menganalisis faktor-faktor yang mempengaruhi keputusan mahasiswa manajemen bisnis STIE Mikroskil dalam keikutsertaaan bisnis Multi Level Marketing (MLM). Metode yang digunakan dalam penelitian ini adalah pendekatan survey, Metode pengumpulan data dilakukan dengan memberikan daftar pertanyaan tertulis dan studi dokumentasi. Metode analisis data yang digunakan adalah Regresi Linear Berganda dengan menggunakan software SPSS. Hasil penelitian yang telah dilakukan secara simultan modal yang kecil, waktu yang fleksibel, tidak membutuhkan pengalaman dan dapat menentukan penghasilan berpengaruh prositif dan signifikan terhadap keputusan mahasiswa pada STIE Mikroskil. Secara parsial modal yang kecil berpengaruh positif dan signifikan terhadap keputusan mahasiswa. Secara parsial waktu yang fleksibel berpengaruh positif dan signifikan terhadap Keputusan mahasiswa. Secara parsial tidak membutuhkan pengalaman berpengaruh positif dan signifikan terhadap keputusan mahasiswa. Secara parsial dapat menentukan penghasilan berpengaruh positif dan signifikan terhadap keputusan mahasiswa. Hal ini menunjukkan bahwa dengan dapat menentukan penghasilan memberikan dampak positif pada peningkatan keputusan mahasiswa.
\end{abstract}


Kata kunci :Modal yang kecil, waktu yang fleksibel, tidak membutuhkan pengalaman, dapat menentukan penghasilan dan keputusan mahasiswa

\section{PENDAHULUAN}

Kewirausahaan menjadi suatu yang sangat penting dibicarakan pada saat ini. Dengan tingkat pengangguran menurut data Badan Pusat Statistik (BPS) hingga tahun 2013 sebesar 7,39 juta orang dari total angkatan bekerja sejumlah 118,19 juta orang . Di tengah-tengah sulitnya mencari pekerjaan dengan lapangan kerja yang sangat terbatas, menjadi seorang wirausaha merupakan alternatif pilihan yang terbesar. Dalam lingkungan mahasiswa, tujuan belajar mereka adalah untuk mendapat ilmu pengetahuan yang diharapkan dapat menjadi bekal untuk mencari pekerjaan. Banyak tantangan dan kendala yang mereka hadapi dalam proses belajar mereka. Salah satunya adalah uang yang digunakan untuk biaya hidup dan keinginan untuk meringankan beban orang tua. Kondisi ini menjadi alasan bagi mahasiswa untuk mencoba mencari jalan keluar dengan menjadi seorang wirausaha di waktu senggang mereka.

Dunia mahasiswa yang selalu memiliki dinamika yang tinggi, selalu ingin mencoba sesuatu yang baru . Dengan pemahaman mereka tentang wirausaha melalui teori-teori yang diterima dalam dunia perkuliahan , selalu merangsang mereka untuk mencoba terjun dalam dunia bisnis. Menurut Steinhoff dan Burgess (Suryana , 2003) Wirausaha adalah orang yang mengorganisir, mengelola dan berani menanggung resiko untuk menciptakan usaha baru dan peluang baru.Untuk memperoleh peluang, seorang wirausaha harus memiliki berbagai kemampuan dan pengetahuan (Suryana, 2006). Hal ini yang menjadi tantangan bagi bagi mahasiswa untuk menjadi seorang wirausaha pada saat mereka mulai mengenal bisnis Multi Level Marketing (MLM). Menjalankan bisnis konvensional dan menjalankan bisnis Multi Level Marketing (MLM) perlu sikap entreprenurship yang kuat . Seorang wirausaha selalu berkomitmen dalam melakukan tugasnya hingga memperoleh hasil yang diharapkannya. Ia tidak setengah-setengah dalam melakukan pekerjaannya .karena itu ia selalu tekun, ulet dan pantang menyerah 
(Suryana, 2006). Jiwa kewirausahaan akan mendorong individu untuk menapaki tingkatan-tingkatan karir di dunia MLM (Betz \& Hacket, 1981).

Menurut Sotya, 2007; Multi Level Marketing (MLM) adalah suatu sistem pemasaran untuk menjual barang secara langsung (direct selling) yang dilakukan melalui banyak level (tingkatan) yang biasa dikenal dengan istilah upline (tingkat atas) dan down line (tingkat bawah), dimana seseorang akan disebut upline jika mempunyai downline. Dengan waktu kerja yang tidak dibatasi dan tidak membutuhkan modal yang besar, dan dengan membangun jaringan yang luas melalui nasabah atau anggota groupnya maka semakin besar lah pendapatan yang diperoleh . Hal ini merupakan peluang yang besar bagi mahasiswa untuk mendapatkan penghasilan sendiri dalam jumlah yang besar. Meskipun ada anggapan positif dan negatif dari masyarakat terhadap keberadaan bisnis $M L M$ (Multi Level Marketing), namun pada kenyataan nya ada ratusan ribu bahkan mungkin jutaan orang termasuk di dalamnya kelompok mahasiswa yang ikut serta dalam bisnis $M L M$. Dengan sikap kewirausahaan yang tinggi dan perlu memiliki etos kerja, bisnis MLM memberi peluang yang sama dengan bisnis konvensional untuk menjadikan orang-orang sukses dan kaya.

Mengingat bisnis $M L M$ harus dijalankan dengan kerja keras dan memiliki etos kerja seperti halnya bisnis konvensional. Berdasarkan uraian diatas penulis tertarik untuk melakukan penelitian dengan judul analisis faktor-faktor yang mempengaruhi keputusan mahasiswa manajemen bisnis STIE Mikroskil dalam keikutsertaaan bisnis Multi Level Marketing (MLM).

Berdasarkan uraian latar belakang diatas yang dapat menggambarkan masalah penelitian yang akan dibahas, maka rumusan masalah penelitian yang dapat diambil adalah faktor-faktor apa sajakah yang mempengaruhi keputusan mahasiswa dalam keikutsertaan bisnis Multi Level Marketing (MLM) di STIEMikroskil?. 
TINJAUAN KEPUSTAKAAN

\section{Definisi MLM}

Multilevel Marketing adalah pemasaran yang berjenjang banyak (Gage,2005:1). Clothier dalam Faisol (2003:26) mengemukakan rumusan dasar dari $M L M$ adalah suatu cara atau metode menjual barang secara langsung kepada pelanggan melalui jaringan yang dikembangkan oleh para distributor lepas yang memperkenalkan para distributor berikutnya, pendapatan yang dihasilkan terdiri dari laba eceran dan laba grosir ditambah dengan pembayaran-pembayaran

berdasarkan penjualan total kelompok yang dibentuk oleh sebuah distributor. Menurut Yusuf (2000:5) MLM adalah sistem pemasaran yang menggunakan jaringan kerja.

Menurut Royan (2002) MLM dikenal juga sebagai network marketing merupakan salah satu metode pemasaran wirausaha dengan memanfaatkan sistem jaringan (network). Yusuf (dalam Rozi, 2003) berpendapat bahwa dikatakan network marketing karena merupakan sebuah jaringan kerja pemasaran yang di dalamnya terdapat sejumlah orang yang melakukan proses pemasaran produk/jasa. Secara umum menurut Sabiq (2005) MLM adalah suatu metode bisnis alternatif yang berhubungan dengan pemasaran dan distribusi yang dilakukan melalui banyak level (tingkatan), yang biasa dikenal dengan istilah upline (tingkat atas) dan downline (tingkat bawah). Inti dari bisnis MLM ini adalah digerakkan dengan jaringan, baik yang sifatnya vertikal atas bawah maupun horizontal kiri-kanan atau pun bisa juga gabungan antara keduanya.

\section{Cara Kerja MLM}

Dalam konteks umum, bisnis MLM dilakukan dengan cara menjaring calon anggota yang sekaligus berfungsi sebagai konsumen dan anggota dari perusahaan yang melakukan praktek MLM. Adapun Sabiq (2005) menjelaskan secara terperinci bisnis $M L M$ dilakukan dengan cara sebagai berikut :

a) Mula-mula pihak perusahaan berusaha menjaring konsumen untuk menjadi anggota, dengan cara mengharuskan calon konsumen membeli paket produk perusahaan dengan harga tertentu. 
b) Dengan membeli paket produk perusahaan tersebut, pihak pembeli diberi satu formulir keanggotaan (member) dari perusahaan.

c) Sesudah menjadi anggota maka tugas berikutnya adalah mencari anggota baru dengan cara seperti diatas, yakni membeli produk perusahaan dan mengisi formulir keanggotaan.

d) Para anggota baru juga bertugas mencari calon anggota baru lagi dengan cara seperti diatas yakni membeli produk perusahaan dan mengisi formulir keanggotaan.

e) Jika anggota mampu menjaring anggota yang banyak, maka ia akan mendapat bonus dari perusahaan. Semakin banyak anggota yang dapat dijaring, maka semakin banyak pula bonus yang didapatkan karena perusahaan merasa diuntungkan oleh banyaknya anggota yang sekaligus menjadi konsumen paket produk perusahaan. f) Dengan adanya para anggota baru yang sekaligus menjadi konsumen tetap produk perusahaan, maka anggota yang berada pada level pertama, kedua dan seterusnya akan selalu mendapatkan bonus secara estafet dari perusahaan, karena perusahaan sangat diuntungkan dengan adanya member-anggotabaru tersebut.

\section{Keuntungan dan Keunggulan MLM}

Keuntungan-keuntungan dari MLM yaitu:

a. Menghemat biaya distribusi

Salah satu alternatif untuk penghematan biaya bisa dilakukan dengan melakukan pemasaran melalui MLM. Jalur distribusi yang dipergunakan adalah melalui downline. Daripada membangun outline yang membutuhkan biaya mahal, $M L M$ memanfaatkan pribadipribadi sebagai jalur distribusi mereka. Dengan demikian perusahaan tidak perlu memikirkan biaya operasional untuk jalur 
distribusi ini yang biasanya sekitar $40 \%$ - $60 \%$ dari harga suatu produk.

b. Menghemat biaya pemasaran Pada MLM, pemasaran dilakukan oleh para distributor dengan menggunakan metode dari mulut ke mulut. Dengan demikian perusahaan bisa mengeluarkan uang yang lebih kecil jika dibandingkan dengan pemasaran konvensional. Iklan yang biasanya digunakan sebagai sarana utama untuk memasarkan suatu produk diganti dengan penjelasan dari mulut ke mulut. Sasaran dari iklan $M L M$ adalah orangorang yang mereka kenal, bahkan setiap distributor bisa membuat brosur sendiri dengan biaya sendiri sehingga perusahaan bisa menghemat cukup banyak uang untuk pembuatan materi pemasaran.

c. Menghemat biaya pelatihan Pada perusahaan MLM, biaya pelatihan yang bisanya merupakan biaya yang harus dikeluarkan oleh perusahaan dibuat menjadi tanggungan yang harus dikeluarkan oleh setiap tenaga penjualan. Bahan-bahan pelatihan yang dipergunakan untuk meningkatkan kemampuan para tenaga penjual juga harus mereka dapatkan dengan biaya mereka sendiri. Hal ini juga berlaku ketika para tenaga penjualan ini harus mengikuti acara seminar atau workshop. Dengan kata lain, perusahaan mengalihkan biaya untuk melatih tenaga penjualan kepada tenaga penjualan itu sendiri. Tindakan ini akan membuat perusahaan menghemat sangat banyak uang, bahkan ada beberapa distributor yang mendapatkan uang dari pelatihan ini jauh lebih banyak daripada uang yang didapat dari komisi penjualan produk.

\section{Definisi Kewirausahaan}

Menurut Kamus Bahasa Indonesia, kewirausahaan terdiri dari kata "wira" dan "usaha". "Wira" sendiri berarti pejuang, gagah berani, kesatria, teladan, manusia unggul, berbudi pekerti dan berwatak berani. 
Sedangkan "usaha" adalah kemauan yang gigih untuk meraih sesuatu atau usaha mandiri mengarah pada tenaga dan pikiran dalam mencapai suatu tujuan. Raymond W.Y Kao menyebut bahwa kewirausahaan sebagai suatu proses, yakni proses penciptaan sesuatu yang baru (kreasi baru) dan membuat sesuatu yang berbeda dari yang sudah ada (inovasi) (dalam Lupiyoadi, 2007:4).

Menurut Hendro kewirausahaan adalah kemampuan untuk merangkai dan memberdayakan semua yang dimiliki.

Kewirausahaan menurut Longenecker (2001) ialah seseorang yang berani mengambil keputusan untuk memulai dan menjalankan bisnis. Kewirausahaan menurut Soetadi (2010) merupakan sikap mental dan sifat jiwa yang selalu aktif dalam berusaha untuk memajukan karya baktinya dalam rangka upaya meningkatkan pendapatan di dalam kegiatan usahanya. Selain itu, Soetadi (2010) juga menambahkan bahwa kewirausahaan adalah kemampuan kreatif dan inovatif yang dijadikan dasar, kiat, dan sumber daya untuk mencari peluang menuju sukses.
Dengan demikian dapat kesimpulan bahwa kewirausahaan adalah bentuk sikap berani, kreatif, inovatif, dan siap menempuh segala macam resiko guna mencapai tujuan kesuksesan dari usaha yang dirintis.

\section{Perilaku Kewirausahaan}

Menurut Scarborough dan Zimmerer (Suryana, 2003:14), ada delapan karakteristik sikap dan perilaku kewirausahaan yang berhasil, yaitu:

1. Bertanggung jawab. Wirausaha selalu memiliki rasa tanggung jawab atas usaha-usaha yang dilakukannya baik dalam mengendalikan sumber daya yang digunakan maupun terhadap keberhasilan berwirausaha.

2. Berani mengambil resiko. Wirausaha dalam mengambil tindakan hendaknya tidak didasari oleh spekulasi, melainkan perhitungan yang matang. Ia berani mengambil risiko terhadap pekerjaannya karena sudah diperhitungkan. Oleh sebab itu, wirausaha selalu berani mengambil risiko yang moderat, artinya risiko yang diambil tidak 
terlalu tinggi dan tidak terlalu

rendah. Wirausaha

menghindari situasi risiko

yang rendah karena tidak ada

tantangan, dan menjauhi

situasi risiko yang tinggi

karena ingin berhasil.

3. Percaya diri. Ia cenderung optimis dan memiliki keyakinan yang kuat terhadap kemampuan yang dimilikinya untuk berhasil.

4. Umpan balik. Wirausaha selalu memerlukan umpan balik yang segera. Ia selalu ingin mengetahui hasil dari apa yang dikerjakannya. Tujuan dari umpan balik adalah untuk memberikan informasi untuk menolong individu memahami bagaimana perilakunya mempengaruhi orang lain dan bagaimana penilaian orang lain terhadap perilakunya.

5. Semangat untuk bersaing. Wirausaha harus memiliki semangat dan kerja keras untuk mewujudkan keinginannya demi masa depan yang lebih baik.

6. Berorientasi ke masa depan. Seorang wirausahawan hendaknya seorang yang mampu menatap masa dengan dengan lebih optimis. Melihat ke depan dengan berfikir dan berusaha. Usaha memanfaatkan peluang dengan penuh perhitungan. Orang yang berorientasi ke masa depan adalah orang yang memiliki persepktif dan pandangan ke masa depan. Karena memiliki pandangan jauh ke masa depan maka ia akan selalu berusaha untuk berkarsa dan berkarya. Kuncinya pada kemampuan untuk menciptakan sesuatu yang baru serta berbeda dengan yang sudah ada. Walaupun dengan risiko yang mungkin dapat terjadi, seorang yang perspektif harus tetap tabah dalam mencari peluang tantangan demi pembaharuan masa depan. Pandangan yang jauh ke depan membuat wirausaha tidak cepat puas dengan karsa dan karya yang sudah ada. Karena itu ia harus mempersiapkannya dengan mencari suatu peluang. 
7. Memiliki keterampilan

personal. Pandai

berkomunikasi. Seorang

wirausaha harus dapat

menarik orang lain dengan

tutur kata yang baik, sopan,

jujur dan percaya diri.

Dengan demikian akan memberi kesan kepada orang lain menjadi tertarik dan orang akan percaya dengan apa yang disampaikan.

8. Selalu mencari peluang. berambisi untuk selalu mencari peluang.

Keberhasilan wirausaha

selalu diukur dengan keberhasilan untuk mencapai tujuan. Pencapaian tujuan terjadi apabila ada peluang.

\section{Kerangka Konseptual}

Berdasarkan penjelasan teori maka kerangka konseptual dalam penelitian ini dapat dirumuskan sebagai berikut:

Seorang wirausaha selalu

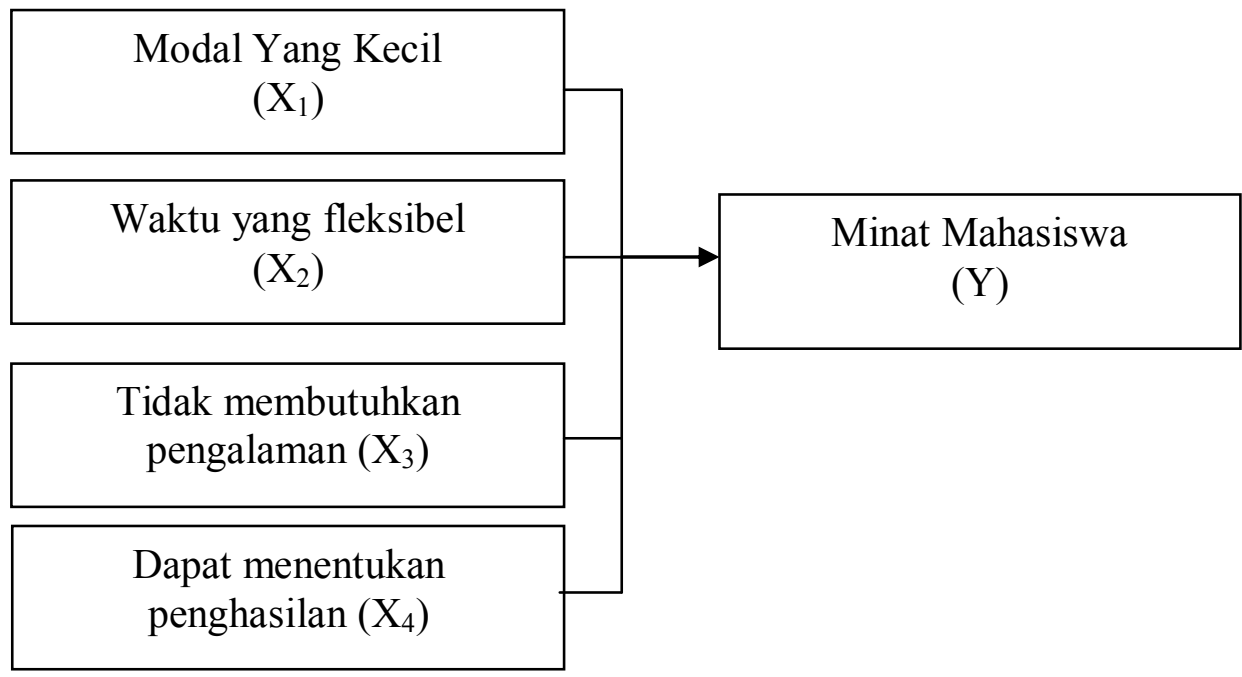

Gambar 2

Kerangka Konseptual 


\section{Hipotesis Penelitian}

Hipotesis penelitian ini adalah

1. Modal yang kecil, waktu yang fleksibel, keinginan untuk berkembang dan dapat menentukan penghasilan secara simultan berpengaruh terhadap keputusan mahasiswa pada STIE Mikroskil.

2. Modal yang kecil secara parsial berpengaruh terhadap keputusan mahasiswa pada STIE Mikroskil.

3. Waktu yang fleksibel secara parsial berpengaruh terhadap keputusan mahasiswa pada STIE Mikroskil.

4. Tidak membutuhkan pengalaman secara parsial berpengaruh terhadap keputusan mahasiswa pada STIE Mikroskil.

5. Dapat menentukan penghasilan berpengaruh terhadap keputusan mahasiswa pada STIE Mikroskil

\section{METODE PENELITIAN}

Definisi Operasionalisasi Variabel

Untuk menyatukan persepsi mengenai variabel yang akan diteliti, maka perlu diberikan definisi operasional yang digunakan dalam penelitian ini.

Variabel penelitian terdiri dari:

1. Variabel bebas yaitu: Modal yang kecil, waktu yang fleksibel, tidak membutuhkan pengalaman, dapat menentukan penghasilan sendiri.

2. Variabel terikatnya yaitu: Keputusan mahasiswa

Variabel bebasnya terdiri dari:

1. Modal: Sejumlah nominal yang seharusnya dimiliki untuk membuka usaha, yang digunakan untuk kegiatan operasional perusahaan misalnya untuk biaya sewa kantor, gaji tenaga kerja, biaya administrasi dll, yang sering menjadi penghambat bagi mahasiswa/i untuk berwirausaha.

2. Waktu yang fleksible: Waktu yang digunakan untuk menjalankan usaha, yang 
sering dibatasi dengan absensi.

3. Tidak membutuhkan pengalaman: Dalam perekrutan tenaga kerja, kualifikasi yang ditentukan oleh perusahaan sering tidak dapat dipenuhi oleh kelompok mahasiswa atau para lulusan perguruan tinggi, tetapi dalam bisnis MLM kualifikasi tenaga kerja tidak ditentukan.

4. Dapat menentukan penghasilan sendiri: Dalam perusahaan konvensional, kenaikan gaji atau pendapatan ditentukan berdasarkan kebijakankebijakan perusahaan, yang dapat menghambat semangat kerja karyawan.

Variabel terikat penelitian ini adalah: Keputusan mahasiswa: Mahasiswa yang ikut serta dalam menjalankan bisnis MLM dilihat dari jumlah mahasiswa yang ikut dalam bisnis MLM .

Penelitian ini menggunakan pengukuran skala likert. Skala likert adalah alat ukur yang digunakan untuk mengukur sikap, pendapat dan persepsi seseorang atau sekolompok orang tentang fenomena sosial. (Sugiono, 2003, 86).

Teknik analisis data yang digunakan dalam penelitian ini adalah teknik regresi linier berganda yang berfungsi untuk mengetahui seberapa besar pengaruh variabel bebas terhadap variabel terikat.

Adapun model yang digunakan dalam perhitungan analisis regresi linier berganda adalah sebagai berikut :

$$
\mathrm{Y}=\mathrm{a}+\mathrm{b}_{1} \mathrm{X}_{1}+\mathrm{b}_{2} \mathrm{X}_{2}+\mathrm{b}_{3} \mathrm{X}_{3}+\mathrm{b}_{4} \mathrm{X}_{4}+\mathrm{e}
$$

Dimana:

$\mathrm{Y}=$ Keputusan mahasiswa

$\mathrm{X}_{1}=$ Modal yang kecil

$\mathrm{X}_{2}=$ Waktu yang fleksibel

$\mathrm{X}_{3}=$ Tidak membutuhkan pengalaman.

$\mathrm{X}_{4}=$ Dapat menentukan penghasilan sendiri

e $=$ error

Pengujian Hipotesis dalam penelitian ini adalah sebagai berikut :

a. Uji Determinasi $\left(\mathrm{R}^{2}\right)$

Uji ini dilakukan untuk mengetahui seberapa besar persentase variabel bebas mampu menerangkan variabel terikat. Uji ini dapat dilihat dengan menggunakan rumus determinan 
b. Uji secara Simultan/Serempak (Uji-F)

Pengujian ini dilakukan untuk melihat apakah semua variabel bebas yang dimasukkan dalam model mempunyai pengaruh secara simultan (serempak) terhadap variabel terikat.

Pengaruh variabel independen terhadap dependen di uji dengan tingkat kepercayaan (confidence interval) 95\% atau pada alpha $\alpha=5 \%$. Untuk menguji apakah hipotesis ditolak atau diterima digunakan statistik uji F :

Jika $\mathrm{F}_{\text {hitung }}<\mathrm{F}_{\text {tabel }}$, maka $\mathrm{H}_{0}$ diterima dan $\mathrm{H}_{\mathrm{a}}$ ditolak, dan Jika $\mathrm{F}_{\text {hitung }}>\mathrm{F}_{\text {tabel}}$, maka $\mathrm{H}_{0}$ ditolak dan $\mathrm{H}_{\mathrm{a}}$ diterima.

b. Uji secara Parsial/Individual (Uji-t)

Uji parsial dilakukan untuk mengetahui pengaruh masing-masing variabel bebas terhadap variabel terikat. Kriteria pengujian dilakukan dengan membandingkan nilai $\mathrm{t}$ hitung dengan t-tabel yaitu : a) Jika t-hitung > t-tabel, tolak $\mathrm{H}_{\mathrm{o}}$ terima $\mathrm{H}_{\mathrm{a}}$ pada taraf signifikan $95 \%$

b) Jika t-hitung $<$ t-tabel, terima $\mathrm{H}_{\mathrm{o}}$ tolak $\mathrm{H}_{\mathrm{a}}$ pada taraf signifikan $95 \%$

\section{HASIL DAN PEMBAHASAN}

Pengujian Asumsi Klasik

Pengujian asumsi klasik digunakan untuk mengetahui model regresi linear berganda dapat digunakan atau tidak. Apabila uji ini terpenuhi maka alat uji dimaksud dapat dipergunakan untuk menguji model yang terdiri dari :

\section{Uji Normalitas}

Uji normalitas dilakukan untuk mengetahui sebuah regresi telah berdistribusi normal atau tidak. Dapat dilihat pada analisis grafik dan analisis statistik berikut ini:

Pada diagram pencar hasil olah data SPSS dengan dasar pengambilan keputusan yakni jika data menyebar disekitar garis diagonal dan mengikuti arah garis diagonal, maka model regresi memenuhi asumsi normalitas. Hasil pengujian normalitas dapat dilihat pada Gambar 1: 


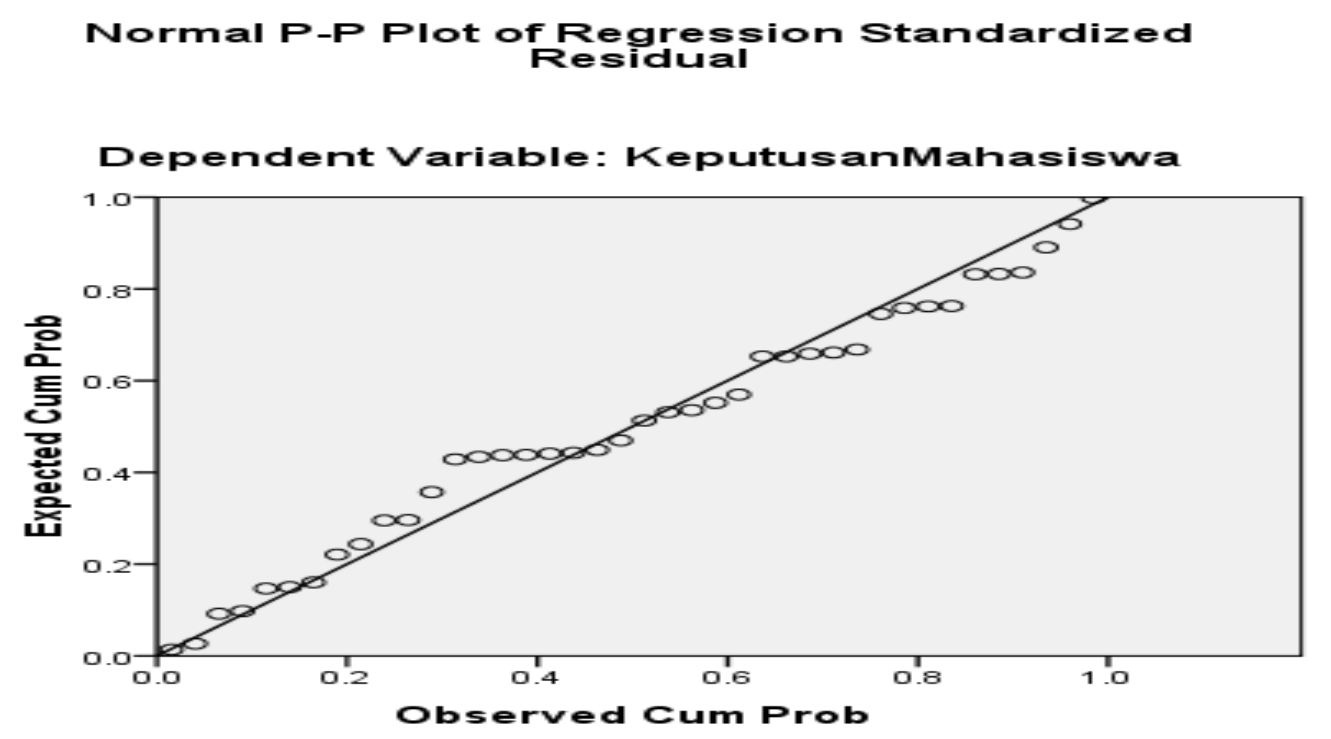

Sumber: Hasil Penelitian, 2015 (data diolah)

Gambar 1 Diagram Pencar Hasil SPSS

Pada Gambar 1 dapat dilihat diagonal dan menunjukkan bahwa data menyebar disekitar garis data berdistribusi normal.

Histogram

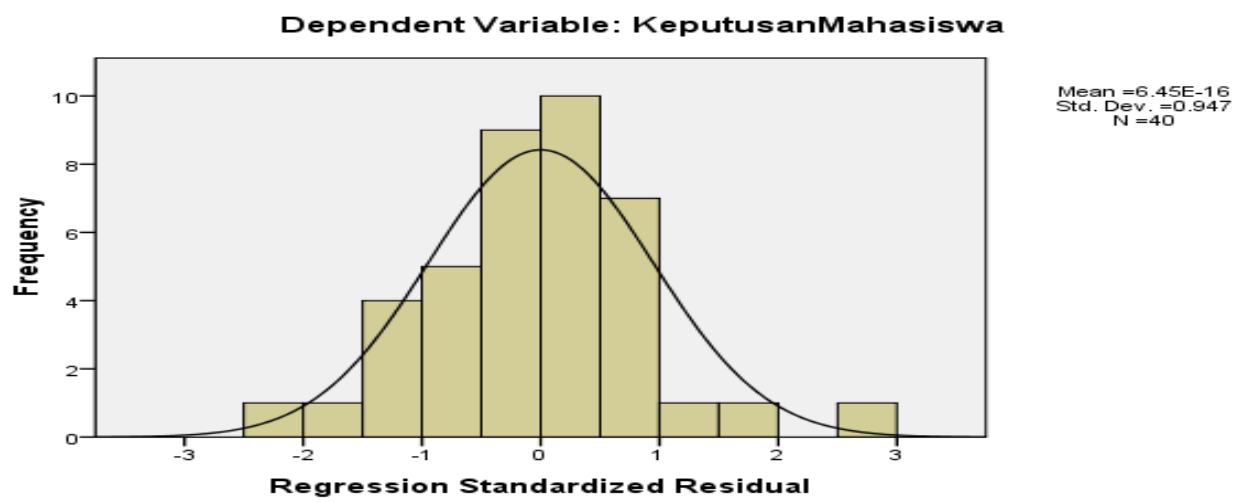

Gambar 2 Grafik Histogram

Pada Gambar 2 data S). Apabila hasil atau nilai berdistribusi normal, hal ini dilihat Kolmogrov-Smirnov (K-S) dan nilai dari pola distribusi merata di sisi kiri Asymp.sig (2-tailed) atau dan sisi kanan.

probabilitasnya di atas 0,05 , maka

Analisis statistik, yakni data telah memenuhi asumsi dengan melihat uji statistik Non- normalitas.

Parametrik Kolmogrov-Smirnov (K- 
Tabel 1

One-Sample Kolmogorov-Smirnov Test

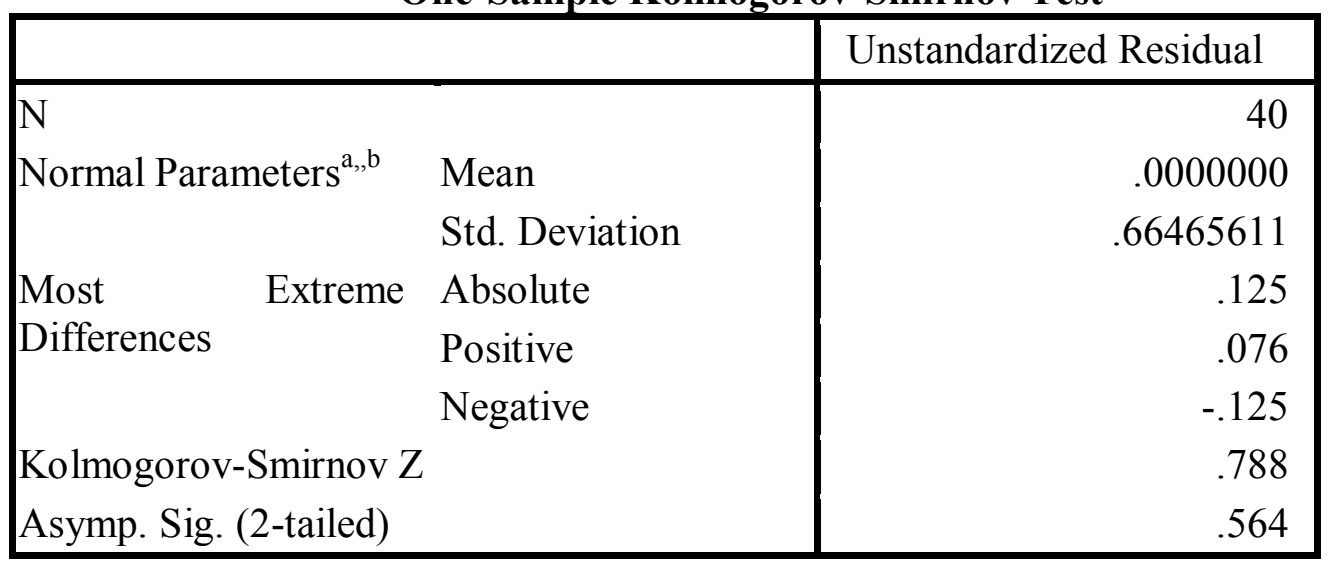

Sumber: Hasil Penelitian, 2015 (data diolah)

Pada Tabel 1 menunjukkan

nilai Kolmogrov-Smirnov (K-S) dengan Asy p.sig (2-tailed) sebesar 0,564 di atas 0,05 maka model yang telah diuji dalam penelitian ini berdistribusi normal.

\section{Uji Multikolonieritas}

Uji multikolonieritas

digunakan untuk mengetahui korelasi antar variabel independent dan ini dapat dilihat dari Variance Inflation Factor (VIF) dengan catatan apabila VIF $>10$ maka diduga mempunyai persoalan multikolinieritas dan apabila VIF $<10$ maka tidak terjadi multikolinieritas. Berdasarkan hasil pengolahan SPSS dilihat pada Tabel 2:

Tabel 2

Hasil Uji Multikolinieritas

\begin{tabular}{|l|r|r|}
\hline \multirow{2}{*}{ Model } & \multicolumn{2}{|c|}{ Collinearity Statistics } \\
\cline { 2 - 3 } & Tolerance & \multicolumn{1}{|c|}{ VIF } \\
\hline 1 ModalYangKecil & .613 & 1.632 \\
WaktuYangFeleksibel & .332 & 3.010 \\
Tidak Membutuhkan Pengalaman & .640 & 1.561 \\
DapatMenentukanPenghasilanSendir & .460 & 2.175 \\
i & & \\
\hline
\end{tabular}

a. Dependent Variable: KeputusanMahasiswa

Sumber: Hasil Penelitian, 2015 (data diolah)

Pada Tabel 2 hasil variabel penghasilan nilai VIF lebih kecil dari modal yang kecil, waktu yang fleksibel, tidak membutuhkan 10 dan niai tolerance mendekati 1. Hal ini menunjukkan tidak terjadi pengalaman dan dapat menentukan gejala multikolonieritas. 


\section{Uji Heteroskedastisitas}

Uji Heteroskedastisitas

bertujuan untuk mengetahui dalam sebuah regresi terjadi kesamaan varians residual, jika varians pengamatan tetap maka disebut homokedasitas, dan jika berbeda disebut heteroskedastisitas, dan model yang baik tentunya tidak terjadi heteroskedastisitas. Dari hasil pengolahan dengan menggunakan SPSS hasil pengolahan data penelitian untuk scatter plot dengan Regression Studentized Residual dapat dilihat pada Gambar 3:

Scatterplot

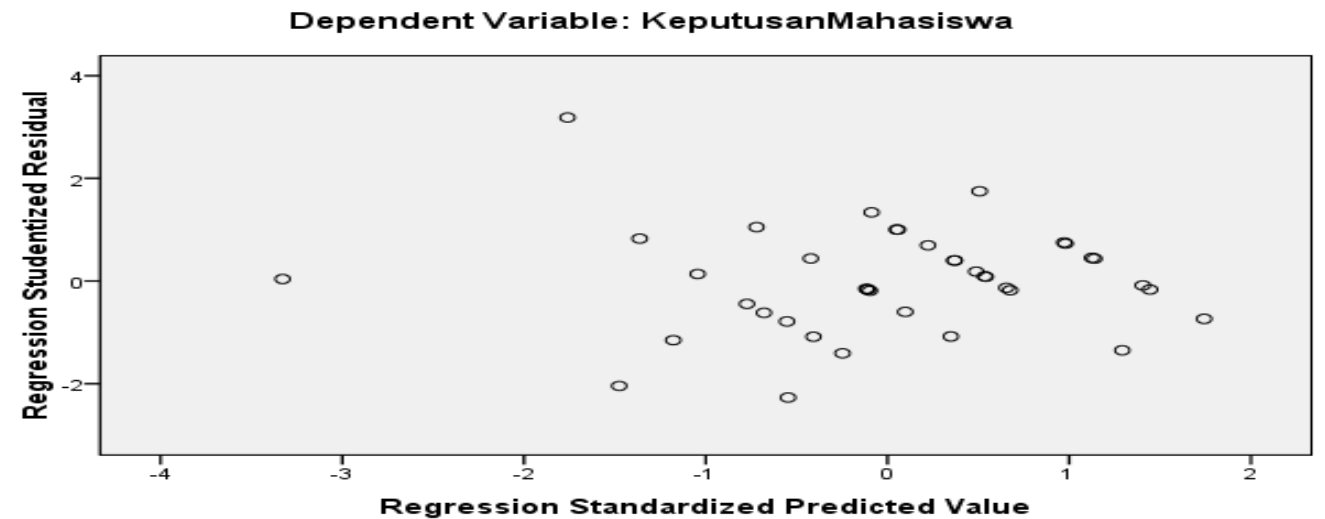

Sumber: Hasil Penelitian, 2015 (data diolah)

\section{Gambar 3 Uji Heteroskedastisitas}

Pada Gambar 3 terlihat titik yang menyebar yang tidak membentuk pola-pola tertentu dan tersebar baik diatas angka 0 pada sumbu Regression Studentized Residual (y) dan berdasarkan gambar tersebut maka tidak terjadi heteroskedastisitas sehingga model regressi layak dipakai untuk memprediksi keputusan mahasiswa berdasarkan variabel independen.
Pada uji Glejser dapat dilihat jika variabel independen singnifikan dibawah 5\% secara statistik, maka di indikasikan terjadinya heteroskedastisitas. Jika probabilitas signifikannya diatas tingkat kepercayaan 5\% maka model regresi tidak terjadi heteroskedastisitas. Berdasarkan hasil pengolahan SPSS dilihat pada Tabel 2 : 
Tabel 2

Hasil Uji Glejser

\begin{tabular}{|l|r|r|r|r|r|}
\hline \multirow{2}{*}{ Model } & \multicolumn{2}{|c|}{$\begin{array}{c}\text { Unstandardized } \\
\text { Coefficients }\end{array}$} & $\begin{array}{l}\text { Standardized } \\
\text { Coefficients }\end{array}$ & & \\
\cline { 2 - 5 } & \multicolumn{1}{|c|}{$\mathrm{B}$} & Std. Error & \multicolumn{1}{c|}{ Beta } & \multicolumn{1}{c|}{ T } & \multicolumn{1}{c|}{ Sig. } \\
\hline 1 (Constant) & 1.192 & .600 & & 1.986 & .055 \\
ModalYangKecil & .036 & .049 & .144 & .730 & .470 \\
WaktuYangFeleksibel & -.173 & .096 & -.480 & -1.799 & .081 \\
TidakMembutuhkan & .064 & .054 & .231 & 1.199 & .239 \\
Pengalaman & & & & & \\
DapatMenentukanPenghasila & -.056 & .099 & -.128 & -.563 & .577 \\
nSendiri & & & & & \\
\hline
\end{tabular}

a. Dependent Variable: abs

Sumber: Hasil Penelitian, 2015 (data diolah)

Berdasarkan pada Tabel 2 dapat dilihat bahwa tingkat signifikansi pada uji-glejser diatas $5 \%$ atau 0,05 . Hal ini menunjukkan bahwa variabel modal yang kecil, waktu yang fleksibel, tidak membutuhkan pengalaman dan dapat menentukan penghasilan tidak terjadi heteroskesdastisitas.

\section{Pengujian Hipotesis}

Analisis Persamaan Regresi Linear

\section{Berganda}

Analisis regresi linear berganda digunakan untuk menguji hipotesis tentang pengaruh secara parsial variabel modal yang kecil, waktu yang fleksibel, tidak membutuhkan pengalaman dan dapat menentukan penghasilan terhadap variabel keputusan mahasiswa. Berdasarkan hasil persamaan regresi linear berganda diperoleh hasil seperti Tabel 3: 
Tabel 3 Hasil Uji Regresi Linier Berganda

\begin{tabular}{|l|c|c|c|c|c|}
\hline \multirow{2}{*}{} & \multicolumn{2}{|c|}{$\begin{array}{c}\text { Unstandardized } \\
\text { Coefficients }\end{array}$} & $\begin{array}{l}\text { Standardized } \\
\text { Coefficients }\end{array}$ & \multicolumn{2}{|c|}{} \\
\cline { 2 - 7 } & B & $\begin{array}{c}\text { Std. } \\
\text { Error }\end{array}$ & Beta & T & Sig. \\
\hline 1 (Constant) & .789 & .985 & & .802 & .428 \\
ModalYangKecil & .205 & .080 & .255 & 2.567 & .015 \\
WaktuYangFeleksibel & .366 & .157 & .313 & 2.323 & .026 \\
TidakMembutuhkan & .213 & .088 & .235 & 2.425 & .021 \\
Pengalaman & & & & & \\
DapatMenentukan & .401 & .162 & .283 & 2.473 & .018 \\
PenghasilanSendiri & & & & & \\
\hline
\end{tabular}

a. Dependent Variable: KeputusanMahasiswa

Sumber: Hasil Penelitian, 2015 (data diolah)

$$
\begin{aligned}
& \text { Berdasarkan Tabel } 3 \text { maka } \\
& \text { persamaan regresi linier berganda } \\
& \text { dalam penelitian ini sebagai berikut: } \\
& \begin{array}{c}
Y=0,789+0,205 X_{1}+0,366 X_{2}+ \\
0,213 X_{1}+0,401 X_{4}
\end{array}
\end{aligned}
$$

1. Nilai konstanta regresi sebesar 0,789 artinya jika modal yang kecil, waktu yang fleksibel, tidak membutuhkan pengalaman dan dapat menentukan penghasilan = 0 maka Keputusan mahasiswa meningkat sebesar 0,789.

2. Koefisien regresi $X_{1}$ untuk variabel modal yang kecil bernilai positif 0,205 artinya bahwa pengaruh variabel modal yang kecil searah dengan peningkatan keputusan mahasiswa. Hal ini menunjukkan bahwa variabel modal yang kecil mempunyai pengaruh positif dalam meningkatkan keputusan mahasiswa.

3. Koefisien regresi $\mathrm{X}_{2}$ untuk variabel waktu yang fleksibel bernilai positif 0,366 artinya artinya bahwa pengaruh variabel waktu yang fleksibel searah dengan peningkatan keputusan mahasiswa. Hal ini menunjukkan bahwa variabel waktu yang fleksibel mempunyai pengaruh positif dalam meningkatkan keputusan mahasiswa.

4. Koefisien regresi $X_{3}$ untuk variabel tidak membutuhkan pengalaman bernilai positif 0,366 artinya bahwa pengaruh variabel tidak membutuhkan pengalaman searah dengan peningkatan 
keputusan mahasiswa. Hal ini menunjukkan bahwa variabel tidak membutuhkan pengalaman mempunyai pengaruh positif dalam meningkatkan keputusan mahasiswa.

5. Koefisien regresi $X_{4}$ untuk variabel dapat menentukan penghasilan bernilai positif 0,401 artinya bahwa pengaruh variabel dapat menentukan penghasilan searah dengan peningkatan Keputusan mahasiswa. Hal ini menunjukkan bahwa variabel dapat menentukan penghasilan mempunyai pengaruh positif dalam meningkatkan keputusan mahasiswa.

\section{Koefisien Determinasi $\left(\mathbf{R}^{2}\right)$}

Koefisien

determinasi merupakan besaran yang menunjukkan besarnya variasi variabel dependen (Keputusan mahasiswa) yang dapat dijelaskan oleh variabel independen (modal yang kecil, waktu yang fleksibel, tidak membutuhkan pengalaman dan dapat menentukan penghasilan). Nilai koefisien determinasi ditentukan dengan nilai Adjusted $R$ Square, dapat dilihat pada Tabel 4:

Tabel 4 Nilai Koefisien Determinasi (Adjusted $R$ Square)

\begin{tabular}{|c|c|c|c|c|}
\hline Model & $\mathrm{R}$ & $\begin{array}{c}\mathrm{R} \\
\text { Square }\end{array}$ & $\begin{array}{l}\text { Adjusted R } \\
\text { Square }\end{array}$ & Std. Error of the Estimate \\
\hline 1 & $.888^{\mathrm{a}}$ & .789 & .764 & .70161 \\
\hline
\end{tabular}

b. Dependent Variable: KeputusanMahasiswa

Sumber: Hasil Penelitian, 2015 (data diolah)

Berdasarkan Tabel 4 di atas nilai adjusted $R$ Square adalah 0,764 , artinya bahwa kemampuan variabel modal yang kecil, waktu yang fleksibel, tidak membutuhkan pengalaman dan dapat menentukan penghasilan dapat menjelaskan variasi dari keputusan pembelian adalah sebesar $76,4 \%$, sisanya sebesar 23,6\% dijelaskan oleh variabel-variabel independen yang tidak diteliti.

\section{Uji Simultan / Uji F}

Uji simultan / uji F dilakukan untuk mengetahui tingkat positif dan signifikansi dari variabel modal yang kecil, waktu yang fleksibel, tidak membutuhkan pengalaman dan dapat menentukan penghasilan sendiri terhadap variabel Keputusan 
mahasiswa dapat dilihat pada Tabel

5:

Tabel 5 Hasil Pengujian Hipotesis Secara Simultan / Uji F

\begin{tabular}{|l|r|r|r|r|r|}
\hline Model & \multicolumn{1}{|c|}{$\begin{array}{c}\text { Sum of } \\
\text { Squares }\end{array}$} & df & \multicolumn{1}{c|}{$\begin{array}{c}\text { Mean } \\
\text { Square }\end{array}$} & F & Sig. \\
\hline 1 Regression & 64.271 & 4 & 16.068 & 32.641 & $.000^{\mathrm{a}}$ \\
& 17.229 & 35 & .492 & & \\
Residual & 81.500 & 39 & & & \\
\hline
\end{tabular}

b. Dependent Variable: KeputusanMahasiswa

Sumber: Hasil Penelitian, 2015 (data diolah)

Pada Tabel 5 diperoleh hasil

$\mathrm{F}$ Hitung 32,64 sedangkan $\mathrm{F}$ Tabel pada $\alpha=0,05$ dengan derajat pembilang 4 dan derajat penyebut 35 diperoleh $\mathrm{F}$ tabel 4,02 dari hasil ini diketahui $\mathrm{F}$ hitung $>\mathrm{F}$ tabel, dan signifikansi 0,000 atau lebih kecil dari $\alpha=0,05$ jadi posisi titik uji signifikansi berada pada wilayah penolakan $\mathrm{H}_{0}$ atau dapat disimpulkan $\mathrm{H}_{1}$ diterima yang artinya bahwa modal yang kecil, waktu yang fleksibel, tidak membutuhkan pengalaman dan dapat menentukan penghasilan secara bersama-sama berpengaruh positif dan signifikan terhadap Keputusan mahasiswa.

\section{Uji Parsial / Uji t}

Hasil pengujian hipotesis secara parsial dapat dilihat pada Tabel 6:

Tabel 6 Hasil Uji Hipotesis Secara Parsial / Uji t

\begin{tabular}{|l|r|r|r|r|r|}
\hline \multirow{2}{*}{ Model } & \multicolumn{2}{|c|}{$\begin{array}{c}\text { Unstandardized } \\
\text { Coefficients }\end{array}$} & $\begin{array}{l}\text { Standardized } \\
\text { Coefficients }\end{array}$ & \multicolumn{2}{|c|}{} \\
\cline { 2 - 6 } & \multicolumn{1}{|c|}{ B } & \multicolumn{1}{c|}{$\begin{array}{c}\text { Std. } \\
\text { Error }\end{array}$} & Beta & \multicolumn{1}{|c|}{ T } & Sig. \\
\hline 1 (Constant) & .789 & .985 & & .802 & .428 \\
ModalYangKecil & .205 & .080 & .255 & 2.567 & .015 \\
WaktuYangFeleksibel & .366 & .157 & .313 & 2.323 & .026 \\
TidakMembutuhkan & .213 & .088 & .235 & 2.425 & .021 \\
Pengalaman & .401 & .162 & .283 & 2.473 & .018 \\
$\begin{array}{l}\text { DapatMenentukanPen } \\
\text { ghasilanSendiri }\end{array}$ & & & & & \\
\hline
\end{tabular}

a. Dependent Variable: KeputusanMahasiswa

Sumber: Hasil Penelitian, 2015 (data diolah) 
Pada Tabel 6 hasil uji parsial diperoleh hasil sebagai berikut:

1. Nilai $t$ hitung untuk variabel Modal yang kecil $(2,567)$ lebih besar dibandingkan dengan nilai $\mathrm{t}$ tabel $(1,68)$, atau nilai sig $\mathrm{t}$ untuk variabel modal yang kecil $(0,015)$ lebih kecil dari alpha $(0,05)$. Berdasarkan hasil yang diperoleh maka menolak Ho dan menerima $\mathrm{H}_{1}$ untuk variabel modal yang kecil. Dengan demikian, secara parsial modal yang kecil berpengaruh positif dan signifikan terhadap keputusan mahasiswa. Hal ini memberi arti bahwa modal yang kecil berpengaruh nyata dalam meningkatkan keputusan mahasiswa.

2. Nilai $\mathrm{t}$ hitung untuk variabel Waktu yang fleksibel (2,323) lebih besar dibandingkan dengan nilai $\mathrm{t}$ tabel $(1,68)$, atau nilai sig t untuk variabel waktu yang fleksibel $(0,026)$ lebih kecil dari alpha $(0,05)$. Berdasarkan hasil yang diperoleh maka menolak $\mathrm{H}_{0}$ dan menerima $\mathrm{H}_{1}$ untuk variabel waktu yang fleksibel. Dengan demikian, secara parsial waktu yang fleksibel berpengaruh positif dan signifikan terhadap keputusan mahasiswa. Hal ini menunjukkan bahwa dengan adanya waktu yang fleksibel memberikan dampak positif pada peningkatan keputusan mahasiswa.

3. Nilai $\mathrm{t}$ hitung untuk variabel Tidak membutuhkan pengalaman $(2,425)$ lebih besar dibandingkan dengan nilai $\mathrm{t}$ tabel $(1,68)$, atau nilai sig $\mathrm{t}$ untuk variabel tidak membutuhkan pengalaman $(0,021)$ lebih kecil dari alpha $(0,05)$. Berdasarkan hasil yang diperoleh maka menolak $\mathrm{H}_{0}$ dan menerima $\mathrm{H}_{1}$ untuk variabel tidak membutuhkan pengalaman. Dengan demikian, secara parsial tidak membutuhkan pengalaman berpengaruh positif dan signifikan terhadap keputusan mahasiswa. Hal ini menunjukkan bahwa tidak membutuhkan pengalaman memberikan dampak positif pada peningkatan keputusan mahasiswa.

Nilai t hitung untuk variabel dapat menentukan penghasilan $(2,473)$ lebih besar dibandingkan dengan nilai $\mathrm{t}$ tabel $(1,68)$, atau nilai sig $\mathrm{t}$ 
untuk variabel dapat menentukan penghasilan $(0,021)$ lebih kecil dari alpha $(0,05)$. Berdasarkan hasil yang diperoleh maka menolak $\mathrm{H}_{0}$ dan menerima $\mathrm{H}_{1}$ untuk variabel dapat menentukan penghasilan. Dengan demikian, secara parsial dapat menentukan penghasilan berpengaruh positif dan signifikan terhadap keputusan mahasiswa. Hal ini menunjukkan bahwa dengan dapat menentukan penghasilan memberikan dampak positif pada peningkatan keputusan mahasiswa. Secara parsial variabel dapat menentukan penghasilan yang dominan mempengaruhi keputusan mahasiswa, Maksudnya adalah variabel dapat menentukan penghasilan menentukan dalam meningkatkan keputusan mahasiswa dibandingkan dengan variabel lainnya.

\section{PEMBAHASAN}

Pengaruh Modal yang kecil dan Waktu yang fleksibel terhadap Keputusan mahasiswa

Hasil penelitian yang telah dilakukan secara bersama-sama modal yang kecil, waktu yang fleksibel, keinginan untuk berkembang dan dapat menentukan penghasilan berpengaruh prositif dan signifikan terhadap Keputusan mahasiswa pada STIE Mikroskil. Hal ini menunjukkan bahwa modal yang kecil, waktu yang fleksibel, tidak membutuhkan pengalaman dan dapat menentukan penghasilan berpengaruh nyata dalam meningkatkan keputusan mahasiswa. Secara parsial modal yang kecil berpengaruh positif dan signifikan terhadap keputusan mahasiswa. Hal ini memberi arti bahwa modal yang kecil berpengaruh nyata dalam meningkatkan keputusan mahasiswa. Secara parsial waktu yang fleksibel berpengaruh positif dan signifikan terhadap keputusan mahasiswa. Hal ini menunjukkan bahwa dengan adanya Waktu yang fleksibel memberikan dampak positif pada peningkatan keputusan mahasiswa. Secara parsial tidak membutuhkan pengalaman berpengaruh positif dan signifikan terhadap keputusan mahasiswa. Hal ini menunjukkan bahwa dengan tidak membutuhkan pengalaman memberikan dampak positif pada peningkatan keputusan mahasiswa dan secara parsial dapat menentukan penghasilan berpengaruh positif dan signifikan terhadap keputusan 
mahasiswa. Hal ini menunjukkan bahwa dengan dapat menentukan penghasilan memberikan dampak positif pada peningkatan keputusan mahasiswa. Secara parsial variabel dapat menentukan penghasilan yang dominan mempengaruhi keputusan mahasiswa, Maksudnya adalah variabel dapat menentukan penghasilan menentukan dalam meningkatkan keputusan mahasiswa dibandingkan dengan variabel lainnya.

\section{PENUTUP}

Hasil penelitian yang telah dilakukan secara bersama sama modal yang kecil, waktu yang fleksibel, tidak membutuhkan pengalaman dan dapat menentukan penghasilan berpengaruh prositif dan signifikan terhadap keputusan mahasiswa pada STIE Mikroskil. Hal ini menunjukkan bahwa modal yang kecil, waktu yang fleksibel, tidak membutuhkan pengalaman dan dapat menentukan penghasilan berpengaruh nyata dalam meningkatkan keputusan mahasiswa.

Secara parsial modal yang kecil berpengaruh positif dan signifikan terhadap keputusan mahasiswa. Hal ini memberi arti bahwa modal yang kecil berpengaruh nyata dalam meningkatkan Keputusan mahasiswa. Secara parsial waktu yang fleksibel berpengaruh positif dan signifikan terhadap keputusan mahasiswa. Hal ini menunjukkan bahwa dengan adanya waktu yang fleksibel memberikan dampak positif pada peningkatan keputusan mahasiswa. Secara parsial tidak membutuhkan pengalaman berpengaruh positif dan signifikan terhadap keputusan mahasiswa. Hal ini menunjukkan bahwa dengan tidak membutuhkan pengalaman memberikan dampak positif pada peningkatan keputusan mahasiswa dan secara parsial dapat menentukan penghasilan berpengaruh positif dan signifikan terhadap keputusan mahasiswa. Hal ini menunjukkan bahwa dengan dapat menentukan penghasilan memberikan dampak positif pada peningkatan keputusan mahasiswa. Secara parsial variabel dapat menentukan penghasilan yang dominan mempengaruhi keputusan mahasiswa 


\section{DAFTAR PUSTAKA}

Dewanti, Retno., 2008. Kewirausahaan, Jakarta: Mitra Wacana Media.

Faisol, Muhammad, 2003. MLM Ideal Antara Konsep dan Strategi, Bahana Mandiri Sentosa, Jakarta.

Gage, Randy., 2005. How to build a Multi Level money machine ; dari a-z tentang MLM dan bagaimana MLM mewujudkan mimpi anda. Gramedia Pustaka Utama, Jakarta.

Hendro., 2011. Dasar-Dasar Kewirausahaan: Panduan Bagi Mahasiswa Untuk Mengenal, Memahami, Dan Memasuki Dunia Bisnis, Erlangga, Jakarta.

Longnecker, J., Carlos, W. M., \& Petty, W. J., 2001. Kewirausahaan manajemen usaha kecil. Terjemahan thomson learning. Jakarta: Salemba Empat.

Lupiyoadi, Rambat., 2007. Entrepreneur:From Mindset To Strategy, Edisi Ketiga, Lembaga Penerbit Fakultas Ekonomi Universitas Indonesia, Jakarta.

Nistains, Van., 2005. MLM Plus. Andi Offset, Yogyakarta.

Peter F. Drucker., 1994. Inovasi dan Kewiraswastaan Praktek dan Dasardasar, Gelora Aksara. Pratama.

Royan, F. M., 2002. Rahasia sukses menjual (Sumber inspirasi distributor MLM dan salesman). Yogyakarta: PenerbitAndi.

Rozi, M. F., 2003. Budaya industri pemasaran jaringan di Indonesia. Yogyakarta: Netbooks press Yogyakarta.

Rusman Hakim., 1998 Kiat Sukses berwiraswasta, Gramedia, Jakarta.

Sabiq, A., 2005. Multi level marketing. Majalah Al-Furqon edisi 11.

Soetadi, I., 2010. Kewirausahaan. Medan: USU press.

Suryana., 2003. Kewirausahaan, Pedoman Praktis. Kiat dan Proses Menuju Sukses. Penerbit: Salemba Empat, Jakarta. BPFE, Yogyakarta, 
1996.

Tarmizi, Yusuf., 2000. Strategi Multi Level Marketing Secara Cerdas dan Halal, Elex Media Computando Kelompok Gramedia, Jakarta.

Teddy Parwitra., 2000. Seluk Beluk Pengembangan Multi Level Marketing di Indonesia, Manajemen dan Usahawan Indonesia, No. 03 Tahun XXIV Maret. 